\title{
Causal Relationship Between Financial Sector Development in SMEs \& Economic Growth in Southern Africa Region
}

\author{
ABIGAIL CHIVANDI* \\ Faculty of Commerce, Law and Management \\ School of Business Sciences, \\ University of the Witwatersrand \\ No. 1 Jan Smuts Ave, Braamfontein, \\ Johannesburg, 2000 \\ SOUTH AFRICA \\ HAPPINESS MAKUMBE \\ Faculty of Commerce, Law and Management \\ School of Economic and Business Sciences, \\ University of the Witwatersrand, \\ No. 1 Jan Smuts Ave, Braamfontein, \\ Johannesburg, 2000 \\ SOUTH AFRICA \\ OLORUNJUWON SAMUEL \\ Faculty of Commerce, Law and Management, \\ School of Business Sciences, \\ University of the Witwatersrand \\ No. 1 Jan Smuts Ave, Braamfontein, \\ Johannesburg, 2000, South Africa, \\ SOUTH AFRICA
}

\begin{abstract}
This study explores causal relationship between financial sector development in SMEs and economic growth in Zimbabwe using annual time series and the Error Correction Model (ECM) framework. Monetary sector improvement and financial development stayed a controversial issue in Southern African nations. Market analysts have distinctive hypothetical and exact perspectives on the causal connection between monetary sector improvement and financial development. support supply driving speculation that monetary sector improvement prompts financial development \& credit to request pulling speculation which proposes that monetary improvement results from financial development. Study made use of Unit Root Tests, Cointegration, ECM and Granger Causality Tests. Empirical findings revealed a bidirectional relationship between financial sector development in SMEs, economic \& business growth. Business \& Economic Growth enhance a strong and flexible legal system allowing banks to allocate resources (credit) more efficiently to SMEs. Credit should be accessed by all enterprise fairly to encourage the development of indigenous businesses through SMEs.
\end{abstract}

Keywords: - Small Medium Enterprise, Granger Causality, Economic Growth, Time Series, Business Enterprise, Gross Domestic Product

Received: December 13, 2020. Revised: June 4, 2021. Accepted: June 12, 2021. Published: June 25, 2021. 


\section{Introduction}

Financial sector development \& economic growth refers to utilization and use of new technology in innovating which includes widening of financial goods and services, improvement on the availability of information on productive investments, mobilization of savings, facilitating the exchange of goods and services, risk diversification and management and ensuring corporate governance and control, [31], [9]. Times of monetary subsidence have required a basic requirement for innovation, creativity and significantly for small business visionaries. The time has come to remember that the early depression resulted in new technologies and creations that purchased with its new opportunities. Scholastic research and hands-on experience have built up an association among entrepreneurship and innovation.

The survival of businesspersons is exceptionally subject to growing new items and administrations. Numerous specialists are seeing the economic recession as the best time to concentrate on development and innovation through small medium entrepreneurship. Business enterprise and innovation can be unique and challenging, yet on the off chance that the SMEs can withstand, at that point they can receive rich benefits [16]. Unpredictable thoughts that appear to be unfeasible first and foremost can prompt some incredible innovation.

Monetary sector innovation and monetary development alludes to usage and utilization of new innovation in enhancing which incorporates augmenting of monetary labor and products, enhancement for the accessibility of data on useful speculations, assembly of investment funds, working with the trading of labor and products, hazard broadening and the executives and guaranteeing corporate corporate governance and control, [31], [9]. Seasons of financial subsidence have required an essential prerequisite for development, imagination and fundamentally for independent company visionaries. The opportunity has arrived to recollect that the early sorrow brought about new advances and manifestations that bought with its new chances. Educational study and active experience have developed a relationship among business venture and innovation [7].

The endurance of businesspersons is uncommonly liable to developing new things and organizations. Various experts are considering the to be downturn as the best an ideal opportunity to focus on improvement and development through small medium business. Business venture and innovation can be exceptional and testing, yet if the SMEs can withstand, by then they can get rich advantages. Eccentric contemplations that have all the earmarks of being impossible above all else can provoke some unimaginable progression.

\section{Theoretical foundation}

\subsection{Literature review}

Business endeavour and progression both require cash related assistance and support for it to be powerful. Since, they manage monetary turn of events; the Zimbabwean Government used to truly uphold the SMEs development. For example, Infrastructural Development Bank of Zimbabwe (IDBZ) had its significant mission as give monetary help to forthcoming SMEs. It was effectively executed in the period $2010-2015$, [26]. SMEs and innovation are interchangeable key energizers for financial turn of events. Coming from development point of view, headways frequently start change both socially and monetarily decidedly. The more extensive and more profound the market is for instance corporate securities; contract securities and SMEs advances the more fostered the monetary sector and development will shape new strategic policies inside the SMEs. Monetary development can be characterized as expansion in country's real degree of public yield because of schooling/preparing, expansion in nature of assets and upgrades in innovation. Expansion in a country's Total national output (Gross domestic 
product) is utilized to gauge financial development [31]. The progression of monetary sector was intended to once again introduce the market system with expectation of reestablishing proficiency, improving assembly of reserve funds, expanding speculation which prods financial development. The appropriation of ESAP and its replacement programs, the Zimbabwe Program of Monetary and Social Change (ZIMPREST) which was not executed for the period 1996-2000, was a wonderful development in numerous African nations since it was a necessity by Global Money related Asset (IMF) to all nations which were requesting monetary help. Despite assumptions, be that as it may, progression of monetary business sectors didn't improve access. During the Financial Underlying Change Program (ESAP) period from 1991 - 1996 the public authority received changes under the consolidated title of an (ESAP) [21]. The significant goal was to foster the SMEs and improvement of everyday environments of the poor by creating supported financial development, yet the program fizzled at the specialty stage [2]. SMEs and social business came as essential apparatus in inventiveness and development in inspiring the day to day environments. A significant segment of these changes was the activation of assets through loan fee advancement. This was after the public authority had understood that its solid intercession had influenced bank's opposition and productivity which additionally decreased the availability of assets for the most part by the private sector [8]. The monetary progression strategy comprised of changes which numerous analysts saw in very a few distinct measurements. A few scientists proposed monetary innovation changes as seeking after privatization of public monetary establishments, evacuation of limitations to passage into banking, measures pointed toward prodding contest in monetary business sectors, decrease of lawful hold necessities, end of coordinated loaning, prudential guideline measures, measures focused on protections markets improvement and transparency of capital record alongside financing cost progression [23]. The Out of control inflation Period (2006 - 2008) the unreasonable cash supply exuded from the Hold
Bank of Zimbabwe (RBZ) printing cash saw the nation encountering a persistent excessive inflation for the most part between the period 2006 and December 2008 [26]. During this period the bootleg market premium augmented yet it was difficult hauling a sack of cash around to proceed to trade for unfamiliar money. Subsequently, unfamiliar cash theorists consummated their trade through making huge amounts of cash moves through their ledgers.

The shaky macroeconomic climate unfavourably influenced the exhibition of the Zimbabwean monetary sector during the emergency time frame. The Dollarisation Time frame (2009 2015) When the RBZ presented Unfamiliar Trade Authorized Stockrooms and Retail Shops (FOLIWARS) in late 2008, denoting the start of true dollarization, banks were not allowed to charge in unfamiliar money, regardless of the way that their costs were named in unfamiliar cash, and this really expanded their real misfortunes because of liquidity imperative and inability to give liabilities [26]. Therefore the greater part of the banks scaled down their activities by shutting a large portion of the branches in rustic territories, which contrarily affected the dualistic idea of monetary asset dissemination as it left out most of the populace without admittance to banking administrations [27].

have positive downstream effects on other industries, like construction and relations industries [10].

A theoretical background is provided to formulate the structure that holds the theory of a research study. The following discussion provides the theoretical background of this study.

\subsection{Theoretical grounding: The Resource Based View}

The Resource Based View (RBV) [22] is the theoretical orientation underpinning the present study. RBV purports that resources and 
capabilities are important for understanding the sources of sustained competitive advantage and growth by money market firms [11], [4]. From the RBV it can be noted that resources and capabilities involve bundles of tangible and intangible assets. These tangible and intangible assets include an SMEs' management skills, organizational processes and routines, and the knowledge and information it controls which it uses to select and implement its strategies. The successful implementation of strategies by SMEs results in a sustained competitive advantage and growth [18]. Therefore, for this study Causal Relationship Between Financial Sector Development in SMEs and Economic Growth in Southern Africa Region is relevant. Another innovation was the developing of capital markets. The advancement of profound and fluid obligation and value markets is frequently referred to as a key institutional development that energizes the effective allotment of budgetary funding to venture ventures and thus goads high rates of monetary development [12]. Very much created monetary markets particularly those with rights that secure financial specialists advance the productive designation of money to ventures with high rates of return, thusly invigorating reserve funds, speculation, and monetary development. It should, in any case, be valued that in creating nations, including Zimbabwe, where the capital markets have not been such a great amount of dynamic in giving outside market financing to private firms, bank financing turns into a particularly significant determinant of endogenous development [34]. Another improvement has been in the financial segment size, structure and proficiency. Money related middle people are thought to improve asset assignment and store ventures with higher rates of return by coordinating borrowers and loan specialists proficiently and by observing firm conduct [23],[35], [10], [15], [14]. [33] found that more challenge in banking markets raises the development of businesses that depend generally vigorously on outer financing.

\section{The figure below shows real average commercial banks rate for the period 1985 to}

\section{2}

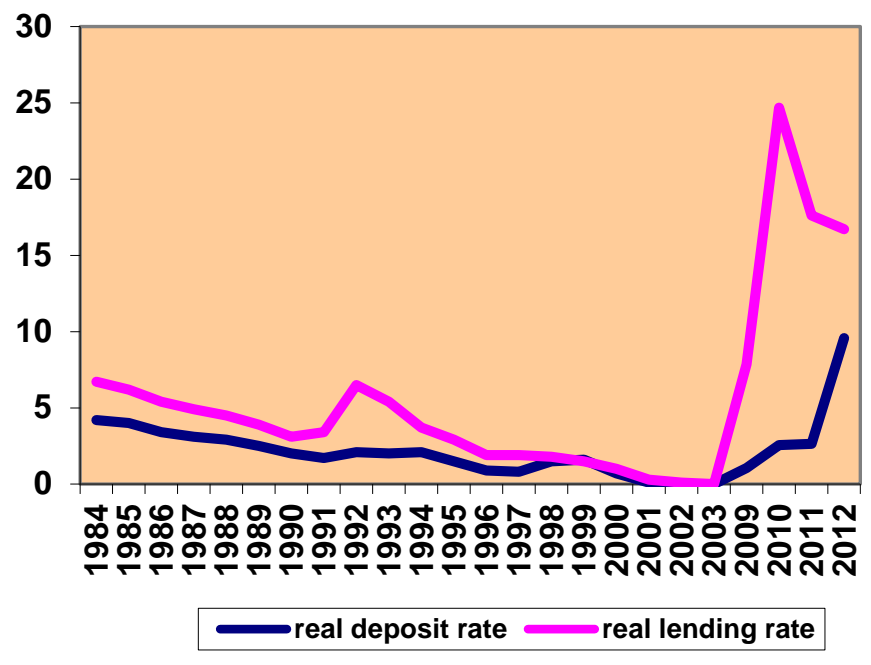

Figure 1; CPI; 2001=100) (extracted from the

RBZ economic research report, 2015)

From 1980 to 1990 the real store rate was fluctuating somewhere in the range of 2.5 and $4 \%$ and from 1991 to 2000 it was changing somewhere in the range of 1 and 2 which was brought about by the money related changes which were executed under the ESAP which deregulated the financial division along these lines expanding the exchange expenses bringing about people diminishing their financial exchanges in light of higher exchange costs. For the period 2001 to 2008 both the real store rate and the real loaning rate was 0 as a result of hyperinflation which was hitting the economy. The approach of the multicurrency routine in 2009 revived monetary exercises in the money related division as appeared by the upward slanting of the chart. Well working banks advance national monetary development, improve the proficiency with which credit is dispensed, and support the development prospects of little and medium endeavours. In any case, the current working condition for banking organizations is described by minor outside subsidizing, low expendable livelihoods, high loan fees and high operational expenses. With the present least necessities by the Central 
Bank, banks' ability to support beneficial financial exercises is compelled [35]. Despite the previously mentioned attributes overwhelming the financial sector, there has been a prominent improvement of the non-bank monetary segment [6]. This incorporates the insurance agencies, contract suppliers, and benefits supports which are fundamentally significant for assembling investment funds and giving business sectorbased wellbeing nets. A solid development of these business sectors will extend access to a wide range of budgetary administrations in the economy [33]. These business sectors further give chances to family venture and long-haul reserve funds. Other nonbank money related organizations in Zimbabwe incorporate the Infrastructure Development Bank of Zimbabwe (IDBZ) and the capital market, the Zimbabwe Stock Exchange that is managed by the Securities Commission of Zimbabwe [26]. The Zimbabwean economy has been marked as irretrievable prompting loss of trust in numerous partners, for example, the worldwide network, the arrangement producers and the general residents. In any case, just a couple of analysts have figured out how to survey the relationship just as affecting approach creators to concentrate and focus on strategies that make the budgetary part changes advance efficiency and monetary development [17], [28]. The study depicts that budgetary innovation and financial development are decidedly related however the issue of causality remains a discussion consequently this investigation attempts to address the discussion.

The distinctive normal for this study is its target of thinking of a more extensive comprehension of the causal relationship of the money related division and monetary development of Zimbabwe during the dollarization time frame. The dollarization time frame is portrayed by the utilization of a steady cash which lifts speculators' certainty and prompts monetary development [21]. Bank's validity had been re- established with the utilization of a progressively steady money as observed by increment in stores. Increment in stores will result in more investment funds preparation [18]. These reserve funds are significant for venture which will prompt financial development. The dollarization time frame is additionally portrayed by low dimensions of expansion which is helpful for speculators to show signs of improvement returns, henceforth the financial specialists will request more advances [17]. No study known by the creator has been done in Zimbabwe during the dollarization time frame with money related development as observed by Internet banking, versatile banking consequently the need of this investigation. Most investigations accomplished for instance, [9], [22], [13] and [3] were cross sectional in nature bringing about some uncertain outcomes. Thusly it is essential to put accentuation on single nation investigation which empowers the catching of explicit components of a nation. This will help in guaranteeing that proportions of money related development picked are explicitly substantial for the nation under study. Proportions of monetary innovation cannot be the equivalent for various nations since the money related division improvement changes with nations. For instance, South Africa's budgetary division is more created than Zimbabwe's. The study is likewise critical when the worldwide money related part is experiencing a liquidity emergency and monetary development for Zimbabwe is dormant. For instance, [35] has endeavoured to examine the relationship concentrating on a unidirectional relationship running from money related improvement to monetary development utilizing cointegration.[28] likewise researched on money related improvement and monetary development nexus utilizing vector autoregressive displaying concentrating on three periods of the budgetary division. Every one of the investigations were done before the dollarization time frame consequently the need 
of this study to discover the sort of relationship which exists when utilizing an increasingly steady cash which empowers venture [33]. From a money related security perspective, more profound, progressively fluid and better working markets are probably going to draw in speculation, as longer-run improvements in building up economies' gross and net capital inflows affirm. [13] This has suggestions as far as proficiency as well as monetary security, since more noteworthy outer money related stuns include more noteworthy extension for increased household advertise unpredictability, as experience completely uncover [31]. Findings from this study will help with ingraining a superior view to approach creators and different partners that the budgetary segment improvement can be an exit plan to accomplish financial development. This will enable them to understand the requirement for predictable and sound arrangements that oversee the money related market tasks. It will assist researchers with bettering get it

\subsection{Hypothetical Literature Review}

Generally, the attention on financial development was on work utilization and capital gathering as reasons for long run development. The scholars accepted monetary development is exogenously decided as it isn't affected by establishments and approaches. [20] Monetary development prohibited the commitment of the money related part to financial development. Present day hypotheses have moved far from the possibility that development is exogenously decided, and they proceed to express that foundations and approaches matter in financial development thusly development is endogenously decided. The neoclassical development hypothesis created by [32] came to be known as the Solow-Swan development model. This hypothesis underlined the significance of reserve funds and capital plan for monetary development. The Solow-Swan hypothesis was gotten from the Harrod-Domar model, and the distinction among them was that the Solow-Swan hypothesis included profitability [11]. This Solow-Swan hypothesis shows that development does not need to be shaky, when the work power is more noteworthy than capital and wages fall in extent to the work power, the wages will increment. Interest rate is exogenous, and it is dictated by expecting a lending rate or a rate of specialized advancement. The Solow-Swan Growth hypothesis likewise accept that reserve funds and speculations choices are exogenous. Factor increment and mechanical development are additionally exogenous [22]. It likewise accepts a consistent come back to scale underway and furthermore that time influences yield just through capital, work and innovation. Land and common assets are not considered.

\subsubsection{The Solow-Swan Growth hypothesis} expresses that total development is shown by an expansion in absolute creation in this manner clarifying a unidirectional relationship running from monetary improvement to financial development. The hypothesis hypothesizes that expansion underway which will prompt monetary development results from increment in capital and mechanical headway which can be acknowledged from reserve funds and ventures. Reserve funds and investment were utilized as intermediaries for money related part development in this study. The endogenous development hypothesis was created by financial analyst [27], [15] to counter a portion of the shortcomings of the Solow-Swan development model. The hypothesis attempts to beat the deficiency of the exogenous development model by building macroeconomic models utilizing microeconomic speculations. It incorporates new ideas of human capital, which is the aptitude to build specialists' profitability [15]. The hypothesis recognizes the way that 
arrangement estimates, for example, sponsorships for innovative work can affect the long run development of the economy [29]. The hypothesis contends that the rate of creation and innovation improvement and the rate of dissemination of innovation rely upon monetary foundations, motivating forces and the job of government. Proper strategies can build the rate of financial development. Endogenous development models depend on two expansive methodologies [17]. The principal approach sees all contributions as reproducible; and the second one depends on externalities as human capital. The reproducibility of the data sources is improved by the condition of innovative work. The reducing peripheral efficiency of the neoclassical model prompts consistent enduring state estimations of capital and yield per labourer is repaid by an expanding nature of apparatus [31]. In this methodology an expansion in the reserve funds rate for all time raises the rate of development of capital and yield per specialist.

The second methodology depends on the suspicion that externalities in the creation procedure, for example, an expansion in the yield dimension of one firm emphatically influences the profitability of the other firm. In this methodology work is endogenously decided and both the amount and nature of work are pertinent [19]. Family units can spare by putting resources into human capital notwithstanding physical capital speculations. Accordingly, family units will be outfitted with abilities on the most proficient method to deal with innovation. Along these lines a small amount of the investment funds is put something aside for capital aggregation and a part is spared to build human capital quality. Along these lines reserve funds rates affect development rate as the development rate is endogenously controlled by the choice to put resources into physical or human capital. The significant impediments of the models talked about so far is that they don't refer to the pretended by the budgetary division administrations [16]. The model just expresses that the offer of total yield spared by the economy is accessible for speculation. The issue inalienable in this supposition that will be that it doesn't consider the spillages and expenses related with the monetary intermediation process. Financial intermediation improves productivity in the circulation of capital, be that as it may, in doing as such there are expenses brought about. The accompanying sector surveys quickly the model with an express presentation of monetary intermediation. Monetary exchanges are influenced by issues of vulnerability, data asymmetry and exchange costs [3]. Budgetary intermediation diminishes a portion of the wasteful aspects coming about because of the three wellsprings of blemished data in various ways: Economies of scale enable monetary go-betweens to accumulate data and diminishing vulnerability at a moderately minimal effort. They can likewise set up uncommon courses of action and contracts, for example, collaterisation of credits to create the right motivating forces to manage data asymmetry [4]. Transactions expenses can be decreased too by intermediating between countless little savers and huge borrowers. Money related delegates along these lines influence development in various ways. First, they influence negligible profitability of capital through their capacity to encourage speculations into higher returns ventures. They prepare reserve funds into ventures. The budgetary framework lessens liquidity hazards by encouraging the administration of dangers both for savers and financial specialists through broadening their portfolio. [29] contended that monetary improvement required moving capital from old business to new, creative strategies for generation. He says this can be accomplished through credit extension. [29] additionally contended that money related go-betweens are significant for innovative and financial advancement. He expresses that well working financial frameworks invigorate mechanical development by recognizing and financing businesspersons who demonstrate the probability of effective usage of new items and creation strategies.

\subsubsection{The McKinnon and Shaw model}


Were created by [20], [9] prior work had distinguished the key procedures associated with financial innovation. Goldsmith demonstrated that as pay rises and monetary action grows money related intermediation, prompting the progressiveness of budgetary resources and liabilities. An expansion in pay and riches, prompts an increment popular for budgetary administrations, for example, cash and monetary resources. They likewise contended that administration control could make the chances and inspirations for budgetary intermediation, for instance, when money related markets are dynamic and sound, controls from government makes open doors for monetary intermediation. They try to create ways to deal with oversee cash and credit that can help decline how much budgetary markets are organized. For [19] the structure of budgetary markets and the restricted open doors for intermediation in creating nations were because of underdevelopment of the economies. He expressed that an economy is organized as in firms and family units are disengaged with the end goal that they bring about higher data cost looking for assets. An economy with a creating budgetary sector ought to hope to have a solid positive connection between venture, reserve funds and cash request. [20] likewise concocted the money related suppression see in which they pushed for the deregulation of loan fees which emphatically influence monetary improvement. To them riches acknowledgment and the rate of development is accepted to be impacted by the rate of profit for real money adjusts. Accepting that, monetary innovation affects economic development however its impact relies upon the loan fee. The higher the loan fee the great the effect on the economy.

On the off chance that it is low monetary development backs off. As per [19] yield is an element of loan fee, venture, investment funds and liquidity of money related middle people. Notwithstanding that, the budgetary suppression hypothesis contends that administration guidelines for the most part in money related markets prompt low financing costs and effect the economy contrarily by decreasing the progression of assets [15]. Banks and other money related establishments are disheartened to loan at low financing costs and this will cause unsettling influences in the portion of profitable assets as reserve funds and ventures will likewise diminish. In this manner if the administration's impedance with the money related framework is limited, real loan fees will go up, support investment funds and increment the volume of credit stretched out by the monetary organizations [32]. The essential for fruitful deregulation is free passage and rivalry with the goal that financing costs can change in accordance with equilibrate sparing and venture. This is one reason why Zimbabwean expert wound up deregulating the economy in the mid1990s and surely the money related division has been developing as estimated by budgetary sector intermediaries. [24] recommended two unique perspectives concerning the course of causality between financial innovation and economic development: the supply-driving and request following speculations. The supplydriving theory sets causal relationship running from monetary innovation to economic development. In this view, the formation of monetary organizations and markets expands the supply of money related administrations and therefore prompts real financial development. The interest following speculation, be that as it may, hypothesizes a causal relationship from economic development to financial innovation [28]. To be sure, an expanding interest for money related administrations because of monetary development may prompt an extension in budgetary sector as increment in development will result in expanded interest of monetary administrations.

\subsection{Supply-driving speculation}

Supporters of this speculation accept that money fills in as the fundamental cow of the economy; they see it as a significant part in the economy as it encourages the monetary exercises and, in this way, increment the gainful limit of the economy [24]. They stress that by and large, nations with well-created and complex monetary frameworks had a superior preferred position in such manner. There will be an expansion in private venture and business enterprise which thus will continue long 
run monetary development than those with immature money related segments. Generally, this theory hypothesizes that monetary development is prompted by different factors for the most part its budgetary structure and execution assume a noteworthy job [14]. More development happens if there is government contribution in executing sound arrangements. It further proposes that approach producers ought to be urged to organize money related part arrangements and dedicate regard for variables adding to budgetary division advancement.

\subsubsection{Request driving speculation -}

As opposed to the supply-driving hypothesis, this speculation says that, monetary development isn't brought about by a created budgetary division. Rather the economy develops freely of the impact of money. This hypothesizes as the economy develops this will have overflow impacts on the budgetary division [27]. As the real divisions of the economy develop, the interest for different money related administrations rises, exchange extends; individuals would need to change their creation plants, they would need to wander in different organizations along these lines, implying that advances should be given. They would need to put resources into progressively profitable resources that were already not provided food by the money related part. Considering this view, money related division advancement is development driven [30].

Consequently, this speculation presumes that monetary sector advancement exists when real development has occurred, in this manner as the economy extends, it prompts an expansion popular for certain budgetary instruments [26]. Budgetary organizations will at that point react to this call as they attempt to expand their items prompting a development of these administrations. The job of the monetary sector isn't believed to be principal for development and its response may be considered, consequently, as a dormant one [25]. Another view concerning the bearing of the relationship recommends a bidirectional relationship. This is the criticism speculation. The promoters in such manner remarked that, nations with well-created and complex money related frameworks will thus prompt monetary lifts through mechanical changes and items therefore, extreme interest on budgetary arrangement and administrations is made. As banking organizations successfully react to the requests with various innovations which will animate a higher monetary development. Along these lines, both monetary innovation and economic development are totally commonly reliant, and their relationship could prompt bidirectional causality. [18] says that the comprehension of the job of account in financial development has arrangement suggestions, coordinates and shapes the future approach situated research. Hypothetical models demonstrate that monetary instruments, markets and establishments may emerge to decrease the impacts of data and exchange costs. Money related frameworks may impact lending rates, investment choices, innovation advancement and after that will advance growth over the long haul. A few speculations weight on the favourable circumstances on bank based budgetary frameworks. Other new hypothetical models centre around the communications between money, total development, pay conveyance and neediness decrease. As indicated by [18], nations with better working banks and markets become quicker and better working budgetary frameworks facilitate the outer financing requirements that upset firms and modern extension. Levine further distinguished five key capacities that a budgetary framework gives in making development: Mobilise and pool investment funds, Facilitate the exchange, supporting, broadening and pooling hazard, allocate assets, Monitor supervisors and exercise corporate control, Facilitate the trading of products and ventures

All the previously mentioned elements of money related framework are pertinent in Zimbabwe. As substantiated by [5], the unification of capital makes it hard for a solitary saver to back it, so the monetary establishments assume a significant job of assembling and pooling of assets from various savers. It is the budgetary division which will make the store accessible for beneficial venture which will result in monetary 
development subsequently the designation of assets which are real jobs of money related gobetweens in Zimbabwe. The budgetary part has encouraged the broadening of hazard by increment in financial specialists' portfolio. Borrowers in Zimbabwe had now an assortment of choices to contribute which incorporate purchasing government securities, business papers, physical merchandise and treasury bills. [14] considered an endogenous development model with financial exchanges and demonstrated that they quickened development for two reasons: First, since responsibility for can be exchanged without upsetting the creation procedure. Second, since specialists are permitted to expand portfolios. The model has the sensible ramifications that without financial exchanges, operators would be debilitated to contribute considering hazard avoidance. They additionally quicken development straightforwardly by wiping out untimely capital liquidation which builds firm profitability and in a roundabout way by diminishing liquidity hazard which empowers firm venture.

\subsection{Empirical Literature}

This section presents a review of the literature related to the purpose of this study.

[6] completed an investigation on the connection between budgetary market progression, innovation and financial improvement in the Zimbabwean setting utilizing the pre dollarization, united money related just as monetary information from 1984 to 2006 . The information utilized for the investigation of the relationship was time arrangement. In this investigation he clarifies the development through time of a lot of money related, budgetary and financial factors after some time. The investigation uncovered that there have been a ton of money related elements in Zimbabwe that developed as an endeavour to experience the monetary emergencies that were winning. The consequences of this study demonstrate that money related segment improvement prompts high monetary development. The utilization of unconsolidated information may bring various outcomes from [6] findings. [4] attempted a study on financial innovation and economic development in Sierra Leone with a motivation behind analysing the connection between budgetary improvement and financial development. This study was done since past investigations done by [8] and [12] were not adequate to decide the connection among account and development in Sierra Leone. In looking at the relationship, they embraced the Autoregressive Distributed Lag (ADL) approach over the time of 1970-2008, utilizing real GDP, money related profundity, speculation to GDP proportion and real store rate as their intermediaries. The utilization of ADL which does not provide for bidirectional causality would be wrong for the estimation of causality in Zimbabwe. Their result was that, speculation and real store rate positively affect the real GDP. What's more, that an expansion in real store rate encourages monetary investment funds and increment real salary. The outcomes were in struggle with that of [10] who found a negative however critical relationship for Sierra Leone when outside credit was utilized, and that the relationship was certain yet unimportant when local credit was utilized. The investigation further repudiated with [19] findings that indicated negative effect of monetary improvement on real GDP per capita over the long haul. The proposal delivered is that: arrangement creators ought to encourage the foundation of money related establishments to build credit conveyance to the private segment particularly in rustic regions. To that, they ought to make an empowering domain for productive designation of credit to the private division through the appropriation of changes to reinforce banks' rights and uphold business contracts. This arrangement likewise ought to be embraced in Zimbabwe since most of the rustic ranchers did not approach credit to back their cultivating. This is pivotal for monetary development in Zimbabwe which is an agro-based economy.

[33] did a study on the nexus between financial innovation and economic growth in South Africa. He utilized cointegration and error 
amendment technique together with the Granger Causality test to set up how financial development and economic growth are connected in South Africa. The Granger Causality test outcomes demonstrated that there is commonly a bidirectional connection between financial development and economic growth suggesting that if the economy develops the financial sector division additionally develops and the other way around. The procedure which [33] used will be utilized in this study and check whether similar outcomes will be found. The study suggested that more investigations utilizing more development and money related markers than the ones he utilized should be completed utilizing a similar procedure he utilized. He additionally suggested that the job of value showcases in monetary development likewise should be researched. [31] did a comparable report for Namibia utilizing a similar technique. The outcomes demonstrated that there is a bidirectional connection between money related segment improvement and financial development in Namibia. He additionally recommended that the development and advancement of the monetary sector can cause the Namibian economy to become quicker than its present development rate. He suggested that banks should build their branches around the nation since as indicated by [23] just $50 \%$ of the populace approaches the financial organizations, this could expand their benefit edges and lift development in the economy. [18] completed an investigation to reconsider the cointegration and causal connection between monetary improvement and financial development in the ECOWAS nations. [2] embraced the [13] way to deal with cointegration and the technique for non-causality trial of [34] utilizing yearly timearrangement information that secured the time of 1960-2005. This study uncovered that the long run impact of money related part improvement on monetary development is high in Cape Verde than in Ghana [34]. This demonstrates monetary development is huge in impacting budgetary advancement in the Ivory Coast than in Liberia, this demonstrates the impact of GDP per Capita development is higher in the Ivory Coast than in Liberia. On account of Guinea, it demonstrates that approach changes towards accomplishing money related advancement have prompted moderate financial development. Esso in his investigation accepted that all components in the accumulation have the equivalent financial structure which isn't the situation for all countries particularly creating ones. Various nations have distinctive money related and monetary structures which should be assessed utilizing various intermediaries and approaches. In this way this study will concentrate on nation explicit investigation with explicit intermediaries being utilized which are reasonable for the nation under study.

[28] completed a study on financial segment advancement and economic development nexus in Zimbabwe utilizing Vector Autoregressive (VAR) demonstrating. He found that there is a solid and positive effect of money related sector extending on financial development. Budgetary division impacts the real GDP through assignment of credit to private segment which will be utilized to work up the economy. He utilized credit to the private division as an intermediary for money related advancement which this study additionally utilized in light of the fact that it is a prevalent measure since it takes just that part of the credit to the private sector which is at the core of mixing monetary development. [22] Granger Causality test uncovered a unidirectional impact of monetary improvement on financial development and reasoned that the supply driving theory holds for the instance of Zimbabwe. This investigation utilized the ECM structure to see whether the outcomes will be the equivalent with [28] in conclusion, after examining SACU member countries' financial sectors, [3] discovered that South Africa is dominant and has shown strong evidence of domestic financial intermediation in promoting economic growth. Botswana and Lesotho showed weak results on domestic financial intermediation in promoting economic growth. He recommends that Lesotho should build domestic entrepreneurial capacity, strengthen the legal system and bank supervision in order to improve its domestic financial institutions and the same applies for Swaziland. He used same proxies, yet the SACU countries have different financial structures which needs 
country specific proxies to be used. [1] carried out a study on financial deepening, economic growth and development on selected subSaharan African countries. The outcome of the study was that, there is shallow financing in most SSA countries which is evident enough to explain the slow growth in most of these countries. In most SSA countries, private savings are negative due to low incomes. Also, interest rates in these countries are usually too low to encourage savings and the banks are not reliable enough. [1] recommended that, SSA countries must put in place policies to attract both domestic and foreign investment and they should also improve the volume and structure of savings. A further recommendation he made was that financial development can be achieved if SSA countries direct public policies towards maintaining external competitiveness, promoting structural reforms and encouraging human capital development. Cross country analysis is not appropriate since different countries have different financial and economic structures which need the usage of different proxies.

\section{Materials and Method}

The time series econometric techniques procedures were used to decide the causal connection between monetary turn of events and financial development in Zimbabwe over the period 1990 to 2016. Since the investigation utilized time series information that is dependent on time, there is need to do non-stationarity, unit root tests to test for stationarity of the various factors. The study at that point assessed the cointegration (long run) model and afterward utilized the residuals that were produced from the long run model to test if co integration (long run) relationship exists among the factors recognised for the model. After it was demonstrated that a relationship existed, an Error Correction Model (ECM) (short run model) run model) was determined. The Granger causality test decided course of connection between factors of interest [8]. Causality in econometrics is characterized as the capacity of one variable to anticipate another variable. The two factors, monetary sector improvement and financial development regularly influence each other with circulated slacks. The investigation utilized normal logarithms to help smoothening time arrangement information and furthermore permitted to decipher coefficients as flexibilities.

\subsection{Data Analysis}

Drawing from the literature review and theoretical grounding, conceptual framework/hypothesis were developed. The model tests consist of three research tests: Stationarity Tests, Johansen Cointegration Test, Granger Causality Test. Research Philosophy took a Positivist Paradigm- Targeted population were Southern African emerging countries players in SMEs case of Zimbabwe. 'A period arrangement information is said to be stationary if the mean and change are steady through time and the estimation of the covariance between the double cross time frames depends just on the separation or slack between the double cross time frames and not the real time at which the covariance is registered [11]. Be that as it may, on the off chance that the mean and difference change in tests for various time ranges, at that point the variable is said to be nonstationary. Relapse conditions with nonstationary factors have real restrictions. Among different issues, their t-proportions and the balanced R-square will be overestimated by an enormous extent. In this manner, all tests become invalid. This is known as the fake relapse issue. To maintain a strategic distance from the issue of deceptive relapse, drifted information is differenced to create a stationary arrangement. Although there are a few trials of stationarity, for example, the graphical strategy, the correlogram technique, Phillips Peron Test and the Augmented Dickey Fuller (ADF) test, this study just talked about the graphical strategy and the Augmented Dickey Fuller test. The ADF test is the most prominent stationarity test and it was 
created by Dickey and Fuller in 1970 and was named after them.

\subsubsection{Augmented Dickey-Fuller test -}

The Dickey-Fuller (DF) test is assessed in three distinct structures that are under three diverse invalid speculations.

$$
Y_{t} \text { is a random walk: } \quad \Delta Y_{t}=\delta Y_{t-1}+u_{t}
$$

$Y_{t}$ is a random walk with drift:

$\Delta Y_{t}=\beta_{1}+\delta Y_{t-1}+u_{t} \ldots . .(2)$

$Y_{t}$ is a random walk with drift $\mathbf{\Delta} Y_{t}=\beta_{\mathbf{1}}+\beta_{\mathbf{2}} t+\delta Y_{t-\mathbf{1}}+u_{t}$ ...... (3)

\section{around a stochastic trend:}

where $t$ is the time or pattern variable and $\mathrm{Y}$ indicates the variable to be tried. In every condition, the invalid speculation is that, that infers the presence of a unit root, in this manner the time arrangement is nonstationary. Dismissing the invalid theory suggests that the arrangement is stationary.

The Dickey-Fuller (DF) test expect that the error terms are uncorrelated, hence the utilization of the standard DF test basic qualities would be negated if the error term in the test are connected after some time, damaging the repetitive sound of the DF test. This study utilized an Augmented Dickey-Fully (ADF) test that considers any auto relationship present by including the slacked estimations of the needy variable. This test is utilized for its consistency, precision and genius.

$\Delta Y_{t}=\beta_{\mathbf{1}}+\beta_{\mathbf{z}} t+\delta Y_{t-\mathbf{1}}+\sum_{i=\mathbf{1}}^{m} \alpha_{i} \Delta Y_{t-\mathbf{1}}+u_{t}$

Where $\mathrm{Y}$ is the variable, whose time series properties are being investigated, $\Delta$ is the difference operator, $\mathrm{m}$ is the number of lagged variables, and where $\varepsilon t$ is the random error term.

Granger Causality test - The Granger causality test strategy was favoured in this study to other elective systems considering its great reaction to both huge and little examples. The regular Granger causality test includes the testing of the invalid speculation that monetary improvement (FD) does not cause financial development (Y) and the other way around by essentially running the accompanying two relapses:

$Y_{t}=\alpha_{s}+\sum_{i=\mathbf{0}}^{n} \alpha_{1 i} \Delta Y_{t-\mathbf{1}}+\sum_{i=\mathbf{0}}^{n} \alpha_{2 j} \Delta F D_{t-j}+\mu_{t}$

$F D_{t}=\beta_{0}+\sum_{i=0}^{n} \beta_{i j} \Delta Y_{t-1}+\sum_{i=0}^{n} \beta_{i j} \Delta P D_{t-j}+e_{t}$

where ut and et are the background noise term for the two capacities individually. is the monetary development variable and is the money related improvement variable?

\section{In this model we can have the accompanying various cases:}

Case 1: The slacked $\alpha$ term in the principal condition might be factually unique in relation to zero as a gathering and the slacked $\beta$ term in the second condition may not be measurably not the same as zero. For this situation we have that money related improvement causes monetary development.

\subsection{Measurement instrument -}

Research scales were operationalised, mainly based on previous work. Proper modifications were made for them to fit the current research context and purpose. In this model we can have the accompanying various cases:

Case 1: The slacked $\alpha$ term in the primary condition might be measurably not quite the same as zero as a gathering and the slacked $\beta$ term in the second condition may not be factually not the same as zero. For this situation we have that monetary improvement causes financial development.

Case 2: The slacked $\beta$ term in the second condition might be factually unique in relation to zero as a gathering and the slacked $\alpha$ term in the principal condition may not be measurably not the same as zero. For this situation we have that 
monetary development causes money related improvement.

Case 3: Both arrangements of $\alpha$ and $\beta$ terms are measurably not quite the same as zero in the first and second condition, so we can presume that we have a bi-directional causality.

Case 4: Both arrangements of $\alpha$ and $\beta$ terms are not measurably unique in relation to focus in the first and second condition, so we can reason that monetary improvement is free to financial development.

\subsubsection{Error Correction Model -}

The dynamic normal for monetary development can be evaluated utilizing an ECM which is a method for differencing results in the loss of significant long-run data of the information [25]. ECM is utilized if factors are not stationary in levels. The lost data will be caught by a error revision term. The error adjustment term is separated by running OLS relapse. The error amendment model was determined as pursues:

$\left.\Delta G D P_{t}=\alpha_{0}+\sum_{i=\mathbf{1}}^{k} \alpha_{i} \Delta G D P_{t-i}+\sum_{i=0}^{k} \alpha_{i} \Delta Z_{t-i}+\mu_{\mathbf{1}} E C M_{-\mathbf{1}}+\varepsilon_{t} \ldots \ldots 7\right)$

where: $\mathrm{Zt}$, is a vector of cointegrated factors, ECM-1, is the error redress term slacked once, and, $\varepsilon t$ is a proportion of the transient changes towards their long run qualities. Condition [6] speaks to the over-parameterised error adjustment model which might be hard to translate, and which likewise prompts lost degrees of opportunity. Because of these troubles, [7] thought of the general - to - explicit econometric demonstrating strategy which is straightforward and simple to decipher. This is the system that was connected in this investigation.

\subsubsection{Cointegration -}

Cointegration is characterized as a long run connection of factors that are connected to frame a balance relationship when the individual arrangement themselves are non-stationary in their dimensions, however turned out to be stationary when differenced. Along these lines, it very well may be expressed that cointegration features the presence of a long run harmony to which the framework unites additional time. Two of the generally utilized tests in present day examine for cointegration are the Engle-Granger and the Johansen strategies. This investigation utilized the Granger Causality tests.

From the McKinnon and Shaw hypothesis, the long run model embraced for this investigation will be as per the following: lnGDP-grt $=\beta 0+$ $\beta 1 \operatorname{lnRrt}+\beta 2 \operatorname{lnLiqt}+\beta 3 \operatorname{lnSavt}+\beta 4 \operatorname{lnCrt}+$ $\beta 5 \ln I n f l t+\beta 6 \ln I n v t+\beta 7 \ln$ TOt + ut.$(8)$ where, GDP speaks to monetary development, $\mathrm{Rr}$ measures the real loan cost, Liq is the liquidity proportion, Sav is the reserve funds proportion, Inv is the venture proportion, $\mathrm{Cr}$ is the volume of credit to private segment, Infl is the swelling rate and To is exchange transparency. After testing for the relationship between the two variables, we then execute causality tests to establish which variable causes the other using the granger causality test.

Data sources: data used are annual data covering the period 2000 to 2015 giving a total of 34 time series observations. The time series data was obtained from the Reserve Bank of Zimbabwe, Zimstat and the World Bank Country Statistics. We applied E-views 7 to execute econometric estimations. Statistical properties of data-A variable which is stationary in levels is said to be integrated of order zero, I (0). A variable that becomes stationery after first differencing is said to be integrated of order one or $\mathrm{I}(1)$; and a variable that becomes stationary after second differencing is integrated of order two, I(2).

\subsection{Empirical Results}

\section{Stationarity Tests}

Table 1: StationarityTests 


\begin{tabular}{|l|l|l|l|l|}
\hline Variable & T and I & Intercept & None & Conclusion \\
\hline GDP_gr & 7.585355 & 7.602358 & 3.880356 & $\mathrm{I}(1)$ \\
& 0.0000 & 0.0000 & 0.0003 & \\
\hline Credit & 5.587755 & 7.902358 & 8.025356 & $\mathrm{I}(1)$ \\
& 0.0007 & 0.0000 & 0.0000 & \\
\hline Inflation & 5.436530 & 5.091486 & 9.508065 & $\mathrm{I}(0)$ \\
& 0.0005 & 0.0002 & 0.0000 & \\
\hline Lrates & 8.014722 & 3.671798 & 8.221964 & $\mathrm{I}(1)$ \\
& 0.0000 & 0.0006 & 0.0000 & \\
\hline Savings & 4.847742 & 4.386806 & 6.794469 & $\mathrm{I}(1)$ \\
& 0.0024 & 0.0015 & 0.0000 & \\
\hline Liquidity & 8.373807 & 8.152094 & 8.072603 & $\mathrm{I}(2)$ \\
& 0.0000 & 0.0000 & 0.0000 & \\
\hline Investment & 7.191261 & 7.244349 & 7.367845 & $\mathrm{I}(1)$ \\
& 0.0000 & 0.0000 & 0.0000 & \\
\hline TO & 6.358073 & 5.012096 & 7.830484 & $\mathrm{I}(1)$ \\
& 0.0000 & 0.0003 & 0.00000 & \\
\hline
\end{tabular}

From the table above, after running the test, it is only inflation which was stationary in levels and all the other variables were non-stationary. Differencing was done and it was found that all the other variables except for liquidity became stationary after differencing once meaning they were integrated of order 1. Liquidity became stationary after second differencing being integrated of order 2 .

\section{Correlation Matrix}

The explanatory variables used in the model are tested for correlation to find if there is no problem of multi-collinearity among the variables and the results are shown in the table below.
Table 2: Correlation Matrix

\begin{tabular}{|c|c|c|c|c|c|c|c|c|}
\hline & $\begin{array}{l}\mathrm{GD} \\
\mathrm{P}_{-} \\
\mathrm{GR}\end{array}$ & $\begin{array}{l}\text { CR } \\
\text { ED } \\
\text { IT }\end{array}$ & $\begin{array}{l}\text { INF } \\
\text { LAT } \\
\text { ION }\end{array}$ & $\begin{array}{l}\text { IN } \\
\text { VE } \\
\text { ST } \\
\text { M }\end{array}$ & $\begin{array}{l}\text { LIQ } \\
\text { UID } \\
\text { ITY }\end{array}$ & $\begin{array}{l}\text { LR } \\
\text { AT } \\
\text { ES }\end{array}$ & $\begin{array}{c}\text { SA } \\
\text { VI } \\
\text { NG } \\
\text { S }\end{array}$ & TO \\
\hline $\begin{array}{r}\text { GDP } \\
\text { GR }\end{array}$ & $\begin{array}{c}1 . \\
00 \\
00 \\
00\end{array}$ & & & & & & & \\
\hline $\begin{array}{l}\text { CRE } \\
\text { DIT }\end{array}$ & $\begin{array}{c}0 . \\
06 \\
96 \\
97\end{array}$ & $\begin{array}{l}1 . \\
00 \\
00 \\
00\end{array}$ & & & & & & \\
\hline $\begin{array}{c}\text { INFL } \\
\text { ATI } \\
\text { ON }\end{array}$ & $\begin{array}{c}- \\
0.6 \\
47 \\
97\end{array}$ & $\begin{array}{c}- \\
0.5 \\
35 \\
37\end{array}$ & $\begin{array}{c}1.0 \\
000 \\
00\end{array}$ & & & & & \\
\hline $\begin{array}{c}\text { INV } \\
\text { EST } \\
\text { MEN } \\
\text { T }\end{array}$ & $\begin{array}{r}0 . \\
48 \\
33 \\
46\end{array}$ & $\begin{array}{l}- \\
0.1 \\
45 \\
42\end{array}$ & $\begin{array}{c}- \\
0.3 \\
295 \\
23\end{array}$ & $\begin{array}{l}1 . \\
00 \\
00 \\
00\end{array}$ & & & & \\
\hline $\begin{array}{c}\text { LIQ } \\
\text { UIDI } \\
\text { TY }\end{array}$ & $\begin{array}{c}- \\
0.4 \\
94 \\
94\end{array}$ & $\begin{array}{c}- \\
0.0 \\
85 \\
05\end{array}$ & $\begin{array}{c}0.6 \\
835 \\
42\end{array}$ & $\begin{array}{l}0.1 \\
90 \\
18\end{array}$ & $\begin{array}{c}1.0 \\
000 \\
00\end{array}$ & & & \\
\hline $\begin{array}{l}\text { LRA } \\
\text { TES }\end{array}$ & $\begin{array}{c}- \\
0.6 \\
44 \\
29\end{array}$ & $\begin{array}{c}- \\
0.4 \\
15 \\
58\end{array}$ & $\begin{array}{c}0.8 \\
769 \\
49\end{array}$ & $\begin{array}{c}- \\
0.4 \\
70 \\
31\end{array}$ & $\begin{array}{c}0.5 \\
065 \\
27\end{array}$ & $\begin{array}{l}1 . \\
00 \\
00 \\
00\end{array}$ & & \\
\hline $\begin{array}{l}\text { SAVI } \\
\text { NGS }\end{array}$ & $\begin{array}{c}0 . \\
54 \\
43 \\
78\end{array}$ & $\begin{array}{c}0 . \\
73 \\
46 \\
26\end{array}$ & $\begin{array}{c}- \\
0.7 \\
429 \\
78\end{array}$ & $\begin{array}{c}0 . \\
22 \\
70 \\
09\end{array}$ & $\begin{array}{c}- \\
0.4 \\
866 \\
3\end{array}$ & $\begin{array}{c}- \\
0.8 \\
11 \\
12\end{array}$ & $\begin{array}{l}1 . \\
00 \\
00 \\
00\end{array}$ & \\
\hline TO & $\begin{array}{c}0 . \\
06 \\
37 \\
86\end{array}$ & $\begin{array}{l}- \\
0.4 \\
42 \\
81\end{array}$ & $\begin{array}{c}0.1 \\
996 \\
11\end{array}$ & $\begin{array}{c}0 . \\
01 \\
26 \\
02\end{array}$ & $\begin{array}{c}- \\
0.5 \\
184 \\
8\end{array}$ & $\begin{array}{r}0 . \\
23 \\
38 \\
61\end{array}$ & $\begin{array}{c}- \\
0.3 \\
92 \\
37\end{array}$ & $\begin{array}{l}1 . \\
00 \\
00 \\
00\end{array}$ \\
\hline
\end{tabular}

The correlation matrix for the variables shows that there was correlation between savings and lending rates and inflation and lending rates. Therefore, to get rid of the problem the variable which was causing correlation was dropped which was lending rates. Thereafter the long run model was specified as:

$\operatorname{lnGDP}-\operatorname{gr}_{\mathbf{t}}=\beta_{1}+\beta_{2} \ln R_{\mathbf{t}}+\beta_{3} \ln \operatorname{Inv}_{\mathbf{t}}+\beta_{4} \ln \mathrm{Cr}_{\mathbf{t}}+$ $\beta_{5} \ln I n f l_{t}+\beta_{6} \operatorname{lnSav}+\beta_{7} \ln \operatorname{Liq}+\beta_{8} \ln \mathrm{TO}+u_{t}$ (9) 
Johansen Cointegration Test

Table 3: Cointegration Test

\begin{tabular}{|c|c|c|c|c|c|c|c|}
\hline $\begin{array}{l}\text { Hypothesi } \\
\text { zed } \\
\text { No. of } \\
\text { CE(s) }\end{array}$ & $\begin{array}{l}\text { Eigen } \\
\text { value }\end{array}$ & $\begin{array}{l}\text { Trace } \\
\text { Statist } \\
\text { ic }\end{array}$ & $\begin{array}{l}5 \% \\
\text { Critica } \\
I \\
\text { Value }\end{array}$ & $\begin{array}{l}\text { Prob } \\
* \\
*\end{array}$ & $\begin{array}{l}\text { Max } \\
\text { Eigen- } \\
\text { Value } \\
\text { Statist } \\
\text { ic }\end{array}$ & $\begin{array}{l}5 \% \\
\text { Critica } \\
I \\
\text { Value }\end{array}$ & $\begin{array}{l}\text { Prob } \\
* \\
*\end{array}$ \\
\hline None* & $\begin{array}{c}0.9096 \\
92\end{array}$ & $\begin{array}{c}246.0 \\
745\end{array}$ & $\begin{array}{c}159.5 \\
297\end{array}$ & $\begin{array}{l}0.00 \\
00\end{array}$ & $\begin{array}{c}74.54 \\
053\end{array}$ & $\begin{array}{c}52.36 \\
261\end{array}$ & $\begin{array}{c}0.00 \\
01\end{array}$ \\
\hline Atmost1* & $\begin{array}{c}0.8528 \\
74\end{array}$ & $\begin{array}{l}171.5 \\
339\end{array}$ & $\begin{array}{c}125.6 \\
154\end{array}$ & $\begin{array}{l}0.00 \\
00\end{array}$ & $\begin{array}{c}59.41 \\
040\end{array}$ & $\begin{array}{c}46.23 \\
142\end{array}$ & $\begin{array}{c}0.00 \\
12\end{array}$ \\
\hline Atmost2* & $\begin{array}{c}0.6689 \\
55\end{array}$ & $\begin{array}{c}112.1 \\
235\end{array}$ & $\begin{array}{c}95.75 \\
366\end{array}$ & $\begin{array}{c}0.00 \\
23\end{array}$ & $\begin{array}{l}34.27 \\
053\end{array}$ & $\begin{array}{l}40.07 \\
757\end{array}$ & $\begin{array}{l}0.19 \\
50\end{array}$ \\
\hline Atmost3* & $\begin{array}{c}0.5909 \\
02\end{array}$ & $\begin{array}{c}77.85 \\
300\end{array}$ & $\begin{array}{c}69.81 \\
889\end{array}$ & $\begin{array}{c}0.00 \\
99\end{array}$ & $\begin{array}{l}27.70 \\
783\end{array}$ & $\begin{array}{c}33.87 \\
687\end{array}$ & $\begin{array}{c}0.22 \\
73\end{array}$ \\
\hline Atmost4* & $\begin{array}{c}0.5178 \\
20\end{array}$ & $\begin{array}{c}50.14 \\
517\end{array}$ & $\begin{array}{c}47.85 \\
613\end{array}$ & $\begin{array}{l}0.03 \\
00\end{array}$ & $\begin{array}{c}22.61 \\
258\end{array}$ & $\begin{array}{c}27.58 \\
434\end{array}$ & $\begin{array}{c}0.19 \\
06\end{array}$ \\
\hline Atmost5 & $\begin{array}{c}0.4482 \\
07\end{array}$ & $\begin{array}{c}27.53 \\
259\end{array}$ & $\begin{array}{c}29.79 \\
707\end{array}$ & $\begin{array}{c}0.08 \\
93\end{array}$ & $\begin{array}{c}18.43 \\
203\end{array}$ & $\begin{array}{c}21.13 \\
162\end{array}$ & $\begin{array}{l}0.11 \\
45\end{array}$ \\
\hline Atmost6 & $\begin{array}{c}0.2052 \\
12\end{array}$ & $\begin{array}{c}9.100 \\
561\end{array}$ & $\begin{array}{c}15.49 \\
471\end{array}$ & $\begin{array}{l}0.35 \\
62\end{array}$ & $\begin{array}{c}7.120 \\
082\end{array}$ & $\begin{array}{c}14.26 \\
460\end{array}$ & $\begin{array}{c}0.47 \\
51\end{array}$ \\
\hline Atmost7 & $\begin{array}{c}0.0618 \\
88\end{array}$ & $\begin{array}{l}1.980 \\
479\end{array}$ & $\begin{array}{c}3.841 \\
466\end{array}$ & $\begin{array}{l}0.15 \\
93\end{array}$ & $\begin{array}{l}1.980 \\
479\end{array}$ & $\begin{array}{l}3.841 \\
466\end{array}$ & $\begin{array}{c}0.15 \\
93\end{array}$ \\
\hline
\end{tabular}

The null hypothesis is that the number of cointegrating vectors is less than or equal to some number against the alternative hypothesis that the number of co-integrating vectors is larger than that number. Both the maximum eigenvalue and trace statistic show that at least one cointegrating vector exist thereby making it necessary for us to construct an error correction model. The trace statistic shows 5 cointegrating equations at $5 \%$ level of significance and the maximum eigen-value statistic shows 2 cointegrating equations.
Table 4: The Long Run Model

\section{Dependent Variable: GDP_GR}

\begin{tabular}{|c|c|c|c|c|}
\hline Variable & $\begin{array}{r}\text { Coeffici } \\
\text { ent }\end{array}$ & $\begin{array}{r}\text { Std. } \\
\text { Error }\end{array}$ & Statistic & Prob. \\
\hline CREDIT & 3.050523 & 1.255610 & -2.429515 & 0.0220 \\
\hline INVESTMENT & $0.004803^{-}$ & 1.580917 & -0.003038 & 0.9976 \\
\hline LIQUIDITY & 3.591404 & 1.424730 & 2.520761 & 0.0179 \\
\hline INFLATION & 4.519292 & 1.197041 & -3.775387 & 0.0008 \\
\hline SAVINGS & 0.938514 & 1.795154 & 0.522804 & 0.6054 \\
\hline TO & 20.67633 & 7.795702 & 2.652273 & 0.0132 \\
\hline
\end{tabular}

$R$-squared: 0.6532

Adjusted R-squared: 0.5889

DW Statistic: 2.3542

\section{F-Statistic: 7.370763 (0.000078)}

The results show that inflation was the only one which was significant at $1 \%$. Trade openness, liquidity and credit were significant at $5 \%$. Investment and savings were not significant.

The Error Correction Model

The error correction term was estimated from running an OLS regression in levels. The lagged variables were included in the ECM model, where (-1) was the first lag of the variables and $(-2)$ represented the second lag of the variables and resid01(-1) was the lag of the error correction term. The lag of the dependent variable was included since the dependent variable can be explained by its past values. The statistical properties of the model can be 
improved by inclusion of the lagged variable of the dependent variable. Results of the ECM are presented in table 5 below.

Table 5: Dependent Variable: D (GDPt_GR)

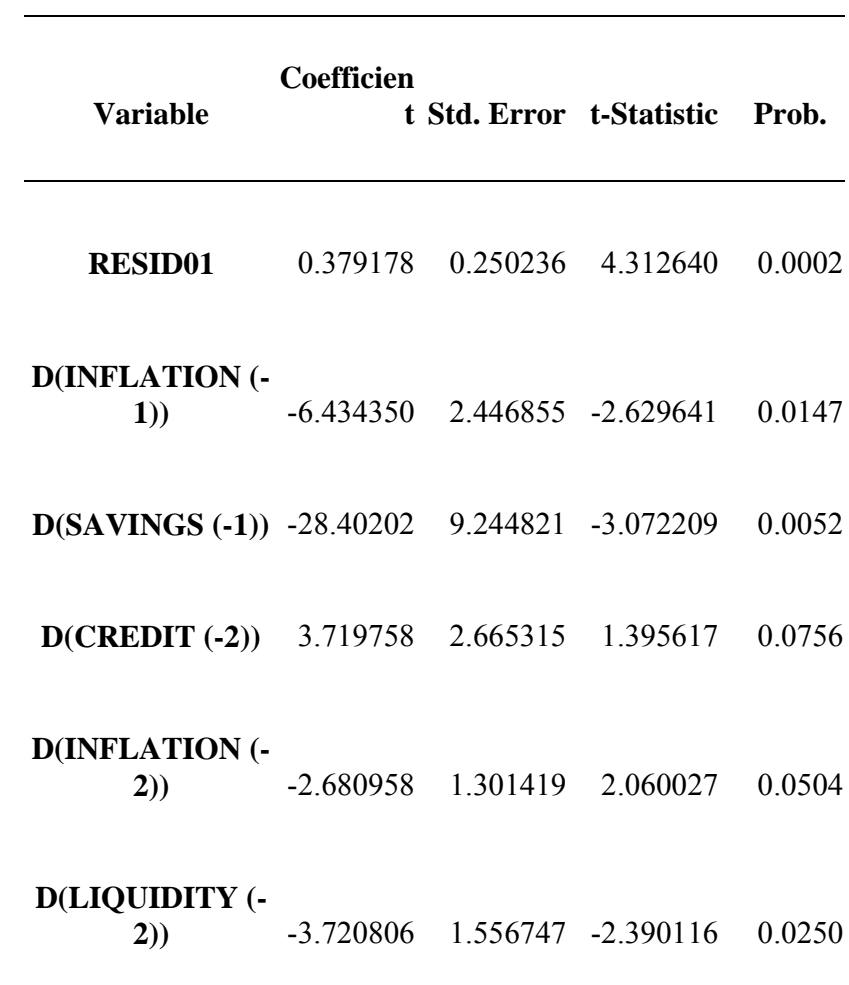

$R$-squared: 0.63864

Adjusted R-squared: 0.5634

DW Statistic: 2.1475

F-Statistic: $6.872265(0.000700)$

Table 5 above demonstrates the consequences of the Error Correction Model. The balanced coefficient of assurance (R2) demonstrates how well the illustrative factors incorporated into the model clarifies the reliant variable. The balanced coefficient demonstrates that $56 \%$ of the variety in the reliant variable is clarified by the factors incorporated into the model. The Durbin-Watson measurement is utilized to test for autocorrelation in the residuals from a relapse investigation. For this situation DW measurement of 2.1 was near 2 appearing progressive error terms were not related. The F- measurement is critical at $1 \%$ demonstrating that the model fits the information. The coefficients are multipliers that depict the size of the impact the free factors are having on the reliant variable. The signs on the coefficients demonstrate the course of the connection between the reliant and free factors. For this situation the greater part of factors has the normal signs. Swelling and liquidity were huge at $5 \%$. Both had negative signs inferring that as they decline GDP will build which moreover count with hypothesis. Credit had a positive sign inferring that expansion in credit will result in increment in financial development. Credit is just noteworthy at $10 \%$ in this manner contributing less altogether to financial development. This may on the grounds that a great part of the credit is directed to the administration, and little will be given to the private sector and won't be open to the larger part who may plant it once again into the economy. Investment funds has a negative coefficient inferring that as reserve funds build, GDP falls. This is in opposition to desires and hypothesis as an expansion in reserve funds implies that more finances will be accessible for speculation, along these lines expanding GDP. Anyway, on account of Zimbabwe, reserve funds originate from the private segment and the private part utilize self-financing for speculation. Along these lines decrease in investment funds demonstrate that the private sector is utilizing its accounts to back their activities. At the end of the day the private part will utilize reserves which should be investment funds to back their venture which will support financial development

\section{Granger Causality Test}

Table 6: Pair wise Granger Causality Test 


\begin{tabular}{|c|c|c|c|c|}
\hline Null Hypothesis: & Obis & F.Statistic & Prob. & $\begin{array}{l}\text { From the table above, GDP growth and liquidity } \\
\text { Granger cause each other at } 5 \% \text { showing that }\end{array}$ \\
\hline $\begin{array}{l}\text { CREDIT does not Granger } \\
\text { Cause GDP_GR }\end{array}$ & 31 & 2.90374 & 0.0727 & $\begin{array}{l}\text { there is a bidirectional relationship where } \\
\text { economic growth has a positive significant }\end{array}$ \\
\hline \multicolumn{2}{|c|}{ GDP_GR does not Granger Cause CREDIT } & 0.59512 & 0.0088 & impact on financial sector development and vice \\
\hline $\begin{array}{l}\text { NFELATION does not Granger } \\
\text { Cause GPPGR }\end{array}$ & 31 & 0.48535 & 0.6229 & $\begin{array}{l}\text { versa. Credit Granger causes GDP growth at } \\
10 \% \text { whilst GDP growth Granger causing credit }\end{array}$ \\
\hline GDP_GR does not Granger Cause & NELATION & 1.12955 & 0.3385 & at $1 \%$. The results supported that the relationship \\
\hline $\begin{array}{l}\text { INVESTMENT does } \\
\text { Granger Cause GDPGR }\end{array}$ & 31 & 2.78372 & 0.0803 & $\begin{array}{l}\text { between economic growth and financial sector } \\
\text { development is bidirectional for the case of }\end{array}$ \\
\hline GDP_GR does not Granger Cause & NVESTMENT & 2.26922 & 0.1235 & \\
\hline
\end{tabular}

\subsection{Discussion of results -}

The target of the investigation explored dynamic (long run and short run) connections between budgetary sector advancement and monetary development in Zimbabwe and henceforth decide the heading of causality. The findings of the study would then be utilized to proffer strategy suggestions to significant partners. In satisfaction of the goals the study utilized co reconciliation and error revision displaying methods. Before setting out on the observational tests, the Augmented Dickey Fuller test was utilized to test for the stationarity of the factors. To test for cointegration, a two-organize EngleGranger strategy was utilized. Error revision model was in this way set to catch the short run elements of the model. The outcomes demonstrated that both money related division improvement pointers are emphatically associated with real GDP over the long haul. Having realized that the relationship exists, the investigation continued with setting up the heading of causality between the budgetary part advancement and real GDP. The aftereffects of the study demonstrate that there is a bidirectional connection between money related division advancement and monetary development. The greater part of the hypotheses recommended that the connection between money related segment advancement and monetary development is 
unidirectional causality, for example, [10] contended that if budgetary middle people produce better data on firms; this will prompt subsidizing all the more encouraging firms and better distribution of assets, consequently financial development. [20] additionally contended that causality kept running from monetary development to budgetary part advancement, since in their model they expressed that the structure of the money related division is controlled by the dimension of financial improvement. Policy suggestions: Having built up the bidirectional connection between money related division advancement and monetary development, the investigation proposes various strategies for upgrading budgetary sector job just as approaches that support financial development. Proposals made to improve money related division advancement are as per the following: Enhance a solid and adaptable legitimate framework-A solid legitimate framework enables banks to dispense assets (credit) even more proficiently. Credit ought to be gotten to by all individuals decently to support the improvement of numerous neighborhood and indigenous organizations.

The patterns in numerous economies demonstrate that there is an expansion in the dimension of SMEs yet most of them bomb because of absence of capital. Along these lines if approaches are set up that gives an equivalent opportunity to credit assignment, the economy will develop because of expanded monetary exercises. To increment on the arrangement of credit there is having to energize the revelation of data in the monetary division, that is, give financial specialists the correct data on every advancement in the budgetary part as this evokes wastefulness. An appropriate legitimate framework with very much characterized property rights is fundamental since it imparts a conviction that all is good in the specialists. An adaptable legitimate framework would enable the economy to change ceaselessly reacting to worldwide needs henceforth money related sector advancement. Enhance rivalry in the monetary division administrations-By expanding the dimension of rivalry, this prompts potential monetary development as more players are in the market. Expanded challenge will likewise build availability to credit because of good conditions that will be offered by various foundations so as to draw in financial specialists. This will build the dimension of interests in the economy. For the speculations to be gainful, there is having to make a helpful macroeconomic condition as a stable macroeconomic condition makes the opening of the economy and consequently the inflow of the money related innovation and thusly prompts monetary development. Also, there is having to make believability in the monetary sector through the formation of an ideal political condition as certainty is a focal column in the exhibition of the money related part. Suggestions made to improve financial development are as per the following: Monetary development results in the making of more openings for work, more training, more social insurance and more preservation of nature. It consequently identifies with a slow increment of the segments of GDP which are utilization, government spending, speculation and net fares. It accordingly infers an expansion in the per capita salary of each resident in this way acquiring quantitative changes the economy. Promote agrarian and mining exercises as they are the foundation of the Zimbabwean economy. This can be accomplished through government financing the sources of info and offering impetuses, for example, more expensive rates on yields and duty exclusions to energize exertion in these sectors. Encourage the exhibition of the little and medium undertakings, so as to build the dimension of work and increment the dimension of development. Open to remote direct speculations. This will improve the dimensions 
of generation, increment business levels and improve exchange the nation. Focus more on improving worldwide relations. This will help financial specialists' certainty and more advantages will stream into the nation through improved exchange relations. We accept the consequences of this study may uncover the need to concentrate on money related framework adjustment in Zimbabwe through political solidness and great administration notwithstanding other monetary changes. Limitations of the study: This investigation is restricted by the inaccessibility of the latest information. It would have been uncovering catching the effect of the portable financial items that were presented in 2012 by the telecom business as they expanded productivity in the money related sector. The optional information utilized in this study originated from three distinct sources which are World Bank, Zimstat and Reserve Bank, which demonstrate the restricted access of information for Zimbabwe. Recommendations on future research: The outcomes from this study uncovered a bidirectional causality between monetary improvement and financial development. Further research should be possible utilizing information from a similar source to maintain a strategic distance from information irregularities. It should be possible utilizing different intermediaries of money related sector advancement like the proportion of private credit to add up to credit and the proportion of monetary foundations resources for ostensible GDP. With the accessibility of information in future, the study could be reached out to fuse the impact of the security and financial exchange markers and other pertinent factors. This investigation utilized an error correction model and cointegration to look at the connection between money related improvement and monetary development. Further looks into should likewise be possible if attempting to discover the relationship of budgetary sector improvement and monetary advancement rather than financial development since such studys should consider significant social financial markets like pay appropriation and destitution destruction.

\section{Conclusion}

Findings uncovered that credit Granger causes Gross domestic product development at 10\% and Gross domestic product development Granger cause credit at $1 \%$. Gross domestic product development and liquidity Granger causes each other at 5\% appearance that causality runs from monetary sector to financial development and the other way around. Strategy creators should zero in on arrangements that influence SMEs improvement in monetary sector development since the two of them emphatically influence financial development. Portraying from the findings above, development and business venture is liable for making occupations and leading financial development. Thus, the Zimbabwean government should zero in on the accompanying strides to support the SMEs. Put resources into instruction and preparing, as advancement and business endeavour require a canny and innovative labour force. Limit and unravel technique for boosting headway and business. Zero in on imaginative work to help headway and business undertaking. Draw in external direct endeavour helps in raising resources for headway and business undertaking. Support worldwide trade that will incite exchange of things, musings and markets which is positive for both progression and undertaking. Assist the relationship with limiting the appraisal, if there ought to emerge an event of a failure in headway and business endeavour. Empower universities and exploration relationship to work with the business portion for a typical benefit. Perceive and award progression and business venture. The outcomes demonstrated that both monetary sector improvement markers are emphatically corresponded with real Gross domestic product over the long haul. Monetary ramifications showed that there is bidirectional connection 
between monetary sector improvement and financial development and upgrade a solid and adaptable overall set of laws that permits banks to dispense assets (credit) all the more proficiently to SMEs. Credit ought to be gotten to by all endeavour decently to support the advancement of native organizations through SMEs. Expanded rivalry in monetary sector brings about expanded openness to credit because of great conditions that are being offered by various foundations to draw in financial backers [6]. This expands the degree of interests in the economy prompting business development. It would have been uncovering catching the effect of the portable financial items that were presented in 2012 by the telecom business as they expanded proficiency in the monetary sector.

\section{References:}

[1] Asteriou, D. and Hall, S. G. (2007). Applied Econometrics, New York, Palgrave MacMillan.

[2] Atkins, R. L. (2006). Financial Development and Economic Growth in Transition Countries in Southern Europe, Andrew Young School of Policy studies.

[3] Aziakpono, M. J. (2003). Financial Intermediation and Economic Growth in Economic and Monetary Union The case of SACU and CMA, Department of Economics, National University of Lesotho, Lesotho.

[4] Aziakpono, M. J. (2004). Financial Development and Economic Growth in Southern Africa, Department of Economics, National University of Lesotho, Lesotho.

[5] Bagehot, W. (1962), Lombard Street, Homewood, IL: Richard Irwin, 1962 edition.

[6] Chirume, A. (2011). The Relationship between financial liberalization, development and economic growth in Zimbabwe, Reserve Bank of Zimbabwe, Economic research paper.

[7] Eita, J. H. and Jordaan, C. A. (2007). A causality analysis between financial development and economic growth for
Botswana, University of Pretoria, Working paper 2007-22.

[8] Engle, R. and Granger, C. (1987). Cointegration and Error Correction: Representation, Estimation and Testing, Econometrica, 55 (2): 251-78.

[9] Goldsmith, R. W. (2009) Financial Structure and Development, Yale University Press, New Haven, Ct.

[10] Greenwood, J. and Jovanovic, B. (1990). Financial development, growth and the distribution of income, Journal of Political Economy, 98, 1076-1108.

[11] Gujarati, D. N. (2003). Basic Econometrics, (4th edition), New York: McGrowHill/Irwin.

[12] Harris, R., 1995. Cointegration Econometric Modelling, Pearson Education, UK.

[13] Hicks, J. (1969). A theory of economic history, Oxford: Clarendon Press.

[14] King, R. G. and Levine, R. (1993). Finance and growth: Schumpeter might be right. Quarterly Journal of Economics 108, 717-737.Retrieved

http://www.microfinancegateway.org/c ontent/article/detail/2111-11k

[15] Levine, R. (2003). More on finance and growth: More finance, more growth? Federal Reserve Bank of St. Louis Review, 85, 31-46.

[16] Levine, R. (1998). The legal environment, banks, and long-run economic growth, Journal of Money, Credit and Banking, 30, 596-620.

[17] Levine, R. (1997). Financial development and economic growth: Views and agenda,

Journal of Economic Literature, 35(2), 688-726.

[18] Levine, R. (2004). Finance and Growth: Theory and Evidence, NBER Working Paper No. 10766, September and Handbook of Economic Growth.

[19] McKinnon, R. I. (1973). Critical values for cointegration tests, Discussion Paper, University of California, San Diego.

[20] McKinnon and Shaw, (1973). Money and Capital in Economic Development, Washington D.C., Brookings Institution, USA. 
[21] Muzulu, J. and Mashonganyika, S. (2011). Beyond the Enclave Chapter twelve: Finance for Inclusive Growth, 473 509, Institute for Development Studies, Harare.

[22] Odhiambo, N. M. (2007). Supply-leading versus demand-following hypothesis: Empirical evidence for three SSA countries, African Development Review, 19, 257-280.

[23] Osungton, A. (1995). The Zimbabwe Economic Structural Adjustment Programme, NDP.

[24] Patrick, H. T. (1966). Financial development and economic growth in underdeveloped countries, Economic Development and Cultural Change, Vol. 14, pp. 174-189.

[25] Ram, R. (1999). Financial Development and Economic Growth: Additional Evidence, Journal of Development Studies, Vol. 35, pp. 164-174.

[26] Reserve Bank of Zimbabwe: (Various publications Quarterly Economic and Stastical Digests and Monthly Bulletins).

[27] Romer, P. (1986). Growth based on increasing returns due to specialization, Cited by Philippe Aghion and Peter Howitt: Endogenous growth theory. MIT Press Cambridge, Massachusetts London, England.

[28] Sakutukwa, T. (2008). Financial Development and Economic Growth Nexus, Economics Department, University of Zimbabwe.

[29] Schumpeter, J. A. (1912). The Theory of Economic Development. Leipzig: Dicker and Humblot. Translated by Redversopie. Cambridge, MA: Harvard University Press, 1934.

[30] Shaffer, R. (1989). Community Economics, Economic Structure and Change in Smaller Communities, Lowa State University Press, Ames, Lowa.

[31] Shaw, E. S. and Garley (1973). Financial Deepening in Economic Development, New York: Oxford University Press.
[32] Solow, R. and Swan, T. (1999). Handbook of Macroeconomics, Elsevier, edition 1, Vol 1, No.1, October.

[33] Sunde, T. (2010). Financial Sector Development and Economic Growth in Namibia. Journal of Emerging Trends in Economics and Management Sciences (JETEMS), 1 (2): 76-80.

[34] ZCTU, (1996). Beyond ESAP:Framework for a Long - Term Development Strategy for Zimbabwe(Harare: Zimbabwe Congress of Trade Unions).

[35] Zivengwa, T. (2005) Financial Sector Development and Economic Growth in Zimbabwe, Economics Department, University of Zimbabwe.

[1] Author, Title of the Paper, International Journal of Science and Technology, Vol.X, No.X, 200X, pp. XXX-XXX.

[2] Author, Title of the Book, Publishing House, $200 X$.

\section{Contribution of individual authors to the creation of a scientific article (ghostwriting policy)}

Author Contributions: Please, indicate the role and the contribution of each author:

Prof. Olorunjuwon Samuel: formulation or evolution of overarching research goals and aims; Development. design of methodology; creation of models.

Dr. Abigail Chivandi: application of statistical, mathematical, computational, or other formal techniques to analyse writeup of the paper and Happiness Makumbe: data collection, executed the experiments and data interpretation, econometrics application.

Follow: www.wseas.org/multimedia/contributorrole-instruction.pdf

\section{Sources of funding for research presented in a scientific article or scientific article itself \\ Report potential sources of funding if there is any Wits University School of Business Science}




\section{Creative Commons Attribution}

\section{License 4.0 (Attribution 4.0}

International , CC BY 4.0)

This article is published under the terms of the Creative Commons Attribution License 4.0

https://creativecommons.org/licenses/by/4.0/deed.en $\underline{\mathrm{US}}$ 